\title{
Objective indicators of pasture degradation from spectral mixture analysis of Landsat imagery
}

\author{
Eric A. Davidson, ${ }^{1}$ Gregory P. Asner, ${ }^{2}$ Thomas A. Stone,${ }^{1}$ Christopher Neill, ${ }^{3}$ \\ and Ricardo O. Figueiredo ${ }^{4}$ \\ Received 15 October 2007; revised 8 February 2008; accepted 17 March 2008; published 23 July 2008.
}

[1] Degradation of cattle pastures is a management concern that influences future land use in Amazonia. However, "degradation" is poorly defined and has different meanings for ranchers, ecologists, and policy makers. Here we analyze pasture degradation using objective scalars of photosynthetic vegetation (PV), nonphotosynthetic vegetation (NPV), and exposed soil (S) derived from Landsat imagery. A general, probabilistic spectral mixture model decomposed satellite spectral reflectance measurements into subpixel estimates of PV, NPV, and S covers at ranches in western and eastern Amazonia. Most pasture management units at all ranches fell along a single line of decreasing PV with increasing NPV and S, which could be considered a degradation continuum. The ranch with the highest stocking densities and most intensive management had greater NPV and S than a less intensively managed ranch. The number of liming, herbiciding, and disking treatments applied to each pasture management unit was positively correlated with NPV and negatively correlated with PV. Although these objective scalars revealed signs of degradation, intensive management kept exposed soil to $<40 \%$ cover and maintained economically viable cattle production over several decades. In ranches with few management inputs, the high PV cover in young pastures declined with increasing pasture age, while NPV and S increased, even where grazing intensity was low. Both highly productive pastures and vigorous regrowth of native vegetation cause high PV values. Analysis of spectral properties holds promise for identifying areas where grazing intensity has exceeded management inputs, thus increasing coverage of senescent foliage and exposed soil.

Citation: Davidson, E. A., G. P. Asner, T. A. Stone, C. Neill, and R. O. Figueiredo (2008), Objective indicators of pasture degradation from spectral mixture analysis of Landsat imagery, J. Geophys. Res., 113, G00B03, doi:10.1029/2007JG000622.

\section{Introduction}

[2] Land cover in the Amazon Basin is increasingly becoming a patchwork influenced by diverse histories of land uses, including cattle pastures in various states of management, productivity, and degradation. Nearly 2 decades ago, Serrão and Toledo [1990] offered the generalization that half of the area converted to cattle pasture in Amazonia was in an advanced state of degradation. This estimate has yet to be substantiated owing to lack of objective methods for quantifying pasture degradation and owing to the unclear definition of "degradation," which may have different meanings for ranchers, ecologists, and policy makers. Although poorly defined and quantified, degrees of degradation may be important with respect to

\footnotetext{
${ }^{1}$ Woods Hole Research Center, Falmouth, Massachusetts, USA.

${ }^{2}$ Department of Global Ecology, Carnegie Institution, Stanford, California, USA

${ }^{3}$ Ecosystems Center, Marine Biological Laboratory, Woods Hole, Massachusetts, USA.

${ }^{4}$ Embrapa Amazônia Oriental, Belem, Pará, Brazil.
}

Copyright 2008 by the American Geophysical Union. 0148-0227/08/2007JG000622\$09.00 future land-use options and rates of $\mathrm{C}$ sequestration, trace gas emissions, and water use.

[3] Spectral mixture analysis, which decomposes individual satellite pixels into constituent cover fractions of surface materials, has been used with a general, probabilistic modeling approach for subpixel cover fractions of photosynthetic vegetation (PV), nonphotosynthetic vegetation (NPV), and bare soil (S) from different types of multispectral and hyperspectral imagery [Asner and Heidebrecht, 2002; Asner et al., 2003, 2004]. In the first field-based study of canopy reflectance properties along pasture chronosequences on both clayey and sandy soils near Santarém, Brazil, Asner et al. [1999] demonstrated that, as pasture age increased, NPV increased. A subsequent study by Asner et al. [2004] used Landsat to show that increasing NPV with pasture age closely tracked decreases in soil nutrient availability as well as decreases in nutrient concentrations in live foliage. Numata et al. [2003, 2007a, 2007b] demonstrated a similar pattern of increasing NPV in aging pastures of Rondônia, although grazing intensity, soil texture and soil order also affected NPV. Accumulation of plant nutrients in senescent necromass, which is detected as NPV, may reduce availability of nutrients needed for the productivity of the 
live grasses. Hence, the NPV may be one viable objective scalar of the degree of pasture degradation. Similarly, overgrazing can also result in the exposure of bare soil, which is another scalar of degradation that can be determined with remote sensing.

[4] The viability of options for agriculture and the rates of recovery of carbon stocks, nutrient stocks, and species diversity may be affected by land-use legacies of degrees of pasture degradation [Davidson et al., 2007; Zarin et al., 2005]. Here we report on an analysis of pasture degradation using objective scalars of PV, NPV, and S derived from spectral mixture analyses of Landsat imagery. We consider these satellite-based estimates of biophysical properties of the vegetation to be objective in the sense that they are mathematical constructs of observed reflectance properties that do not, at least initially, require subjective interpretation. Although pasture degradation can be defined in many ways, some of which involve value judgments, we explore whether a definition of pasture degradation based on these scalars of land cover can be useful across the basin. The goal was to determine if there are consistent responses of land surface reflectance properties to changes in grazing intensity, soil conditions, and management inputs across cattle pastures in the western and eastern Amazonia.

\section{Materials and Methods}

\subsection{Site Descriptions}

[5] Fazenda Vitória is located $6.5 \mathrm{~km}$ northwest of the town of Paragominas, Pará State, Brazil, in eastern Amazonia $\left(2^{\circ} 59^{\prime} \mathrm{S}, 47^{\circ} 21^{\prime} \mathrm{W}\right)$. This area was settled in the early 1960s following the construction of the Belém-Brasilia highway and became a regional center for logging and ranching [Nepstad et al., 1991]. The 3500 ha ranch is a mosaic of primary forest, logged forest, secondary forest, and pasture with moderately dissected topography (Figure 1a). The areas that are now in pasture and secondary forest were originally cleared and burned in 1969. After 6-8 years of pasturing, some of the area was abandoned to fallow. Areas that continue to be actively managed for cattle pastures received management inputs such as disking, $\mathrm{P}$ fertilization ( $\sim 50 \mathrm{~kg} \mathrm{ha}^{-1}$ ), and planting with an African grass (Brachiaria brizantha) in the late 1980s.

[6] Rainfall distribution in this region has a strong seasonality with $<15 \%$ of the total annual precipitation falling between June and November. Average annual precipitation is $1800 \pm 550 \mathrm{~mm}(1972-1994$ mean $\pm 1 \mathrm{SD}$ [Jipp et al., 1998]). Soils of this region are deeply weathered Oxisols (Haplustox) derived from the Belterra clay formation that developed on the top and upper slopes of a Pleistocene terrace. Belterra clays consist mainly of kaolinite, with minor fractions of quartz and hematite, and are widespread at elevations below $200 \mathrm{~m}$ in the Amazon Basin [Clapperton, 1993]. The soils were classified by Sombroek [1966] as Kaolinitic Yellow Latosols (Haplustox, according to USDA Soil Taxonomy), and they contain $60-80 \%$ clay content. Forest soils are acidic with $\mathrm{pH}_{\mathrm{w}}<5.0$ at all depths, whereas pasture soil $\mathrm{pH}$ in water was 5.2 to 5.7 in the top $10 \mathrm{~cm}$ [Markewitz et al., 2004].

[7] Fazenda Nova Vida is located directly adjacent to BR$364,50 \mathrm{~km}$ from the city of Ariquemes in central Rondônia $\left(10^{\circ} 09^{\prime} \mathrm{S}, 62^{\circ} 50^{\prime} \mathrm{W}\right)$. Small amounts of forest on this
19,000 ha ranch were cleared for subsistence settlements as early as 1911, but large-scale land clearing at Nova Vida began in 1972 and continued with additional areas cleared in 1979, 1983, 1987 and 1989. Almost no new forest clearing has occurred since 1989. The ranch is now a mosaic of primary forest, logged forest and pastures (Figure 1b). Nova Vida contains no abandoned pastures and almost no areas of second growth vegetation. Pastures at Nova Vida were planted directly from forest to Panicum maximum, Brachiaria humidicola and Brachiaria brizantha and managed by application of the herbicides picloram and 2,4dinitrophenol and occasional burning through the 1990s. Management since 1998 has included mechanical clearing of woody debris, additional herbiciding, disking and application of lime $\left(0.6 \mathrm{Mg} \mathrm{ha}^{-1}\right)$ and rock phosphate.

[8] Terrain at Nova Vida is gently rolling at $200-500 \mathrm{~m}$ and drained by low-gradient clear water streams. The region is underlain by Pre-Cambrian granitic bedrock of the Brazilian Shield [Projeto Radambrasil, 1978]. The climate of central Rondônia is humid tropical. Annual precipitation is $2254 \pm 266 \mathrm{~mm}(1984-1994$ mean $\pm 1 \mathrm{SD})$. Mean annual relative humidity is $89 \%$, mean daily temperature is $25.6^{\circ} \mathrm{C}$, and mean daily temperature for the warmest and coolest months varies less than $5^{\circ} \mathrm{C}$ [Bastos and Diniz, 1982]. Rainfall has a distinct dry season from June to October and a rainy season from November to May. Rainfall averages $>300 \mathrm{~mm} \mathrm{mo}^{-1}$ during the wettest four months (December-March) and $<40 \mathrm{~mm} \mathrm{mo}^{-1}$ during the driest 3 months (June-August) [Bastos and Diniz, 1982]. Soils at Nova Vida are predominantly weathered Ultisols (Kandiudults, Hapludults) with sandy loam or sandy clay loam texture and surface clay contents of 10-25\% [Neill et al., 1997]. Forest soils have a $\mathrm{pH}_{\mathrm{w}}$ of 4.7-4.9 at all depths and pastures have $\mathrm{pH}_{\mathrm{w}}$ that ranges from 6.0 to 7.2 at the surface to 4.8 to 6.5 at $50 \mathrm{~cm}$.

\subsection{Landsat Imagery}

[9] For comparison between ranches, Landsat imagery was obtained for Fazenda Nova Vida in Rondônia (path/row 231-067; 11 August 2001) and Fazenda Vitória in Pará (path/row 222-62; 6 July 1996). Both dates are in the dry season. A subset of each image was extracted to focus on the region immediately surrounding the ranches. All images were geo-corrected to a common map projection (UTM zones 20 and 23, datum: Clark 1866), and were composed of $30 \mathrm{~m}$ resolution pixels. To compare the effects of seasonality at one site, an additional image for Nova Vida, acquired on 22 May 2002, was used to represent the end of the wet season. Images of Nova Vida acquired on 9 August 1999, 24 August 2000, and 11 August 2001, were also used to compute a multiyear mean image for purposes of comparison with a record of management treatments (see section 2.4). We also include analyses from Asner et al. [2004], who obtained Landsat imagery for ranches south of Santarém, Pará (path/row 227-062; 27 August 1997).

\subsection{Spectral Mixture Analysis}

[10] Prior to analysis, sensor gains and offsets were applied to the imagery to convert from digital number (DN) to exo-atmospheric radiance. The radiance data were then passed to a fully automated version of the $6 \mathrm{~S}$ atmospheric radiative transfer model [Vermote et al., 1997]. 

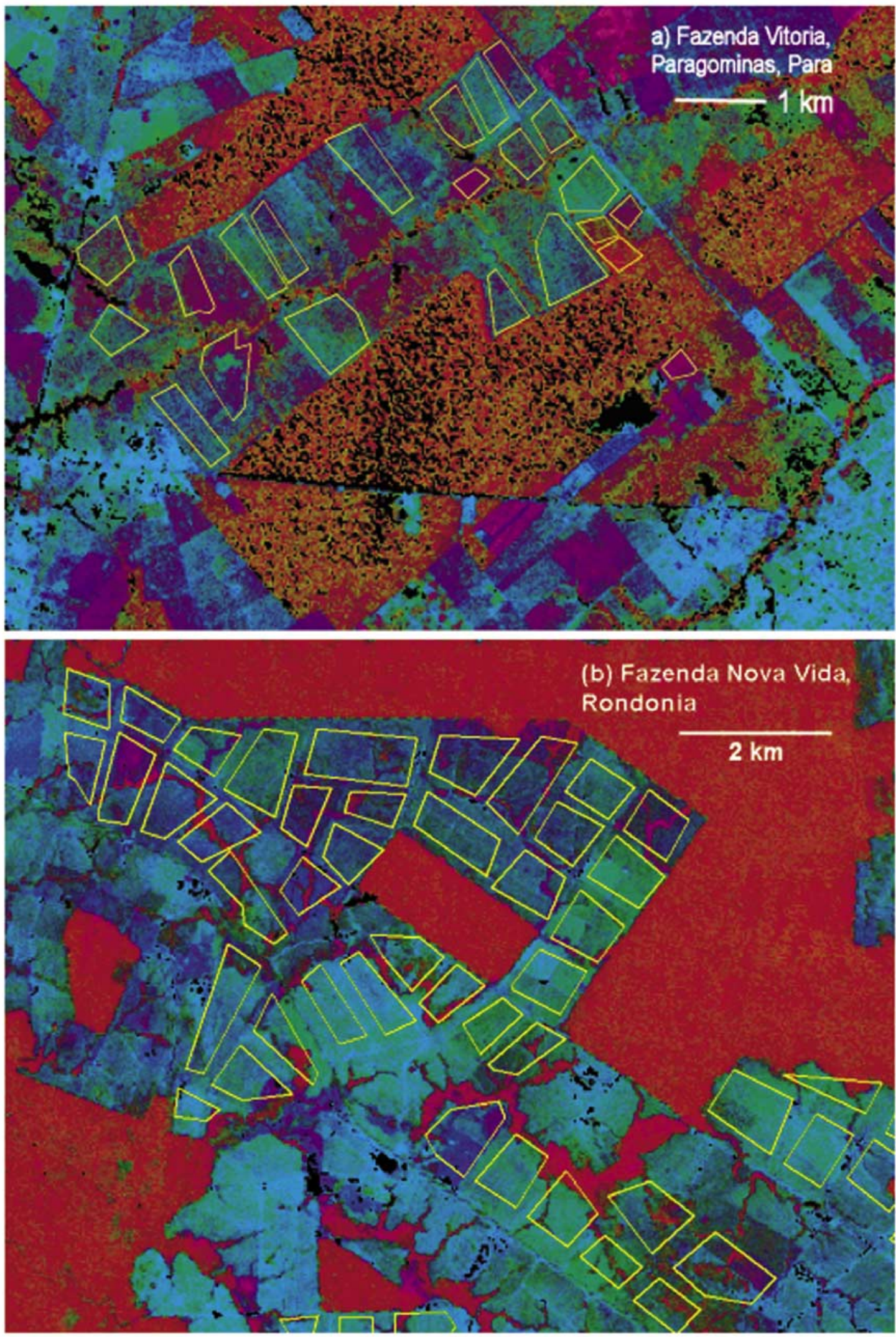

Figure 1 
Aerosol optical thickness and water vapor data taken from the Moderate Resolution Imaging Spectrometer (MODIS) sensor onboard the NASA Terra spacecraft were used as inputs to 6S as described in detail by Asner et al. [2005]. For the Landsat image collected prior to the launch of Terra, we used the long-term average MODIS aerosol and water vapor data from the same month of collection (July), a technique that has proven reliable for correcting Landsat imagery for the spectral mixture analysis approach that is used here [Oliveira et al., 2007]. These steps provided estimates of apparent surface reflectance for Landsat bands $1-5$ and 7.

[11] We used the AutoMCU model [Asner and Heidebrecht, 2002] to decompose each Landsat pixel into fractional cover estimates $(0-100 \%$ cover) of photosynthetic vegetation (PV) canopy, nonphotosynthetic vegetation (NPV), and bare substrate. AutoMCU is fully automated and uses a Monte Carlo unmixing approach to derive uncertainty estimates of the subpixel cover fraction values. The method uses three spectral end-member "bundles," derived from extensive field databases and satellite imagery [Asner et al., 2004, 2005], to decompose each image pixel using the following linear equation:

$$
\begin{aligned}
& \rho(\lambda)_{\text {pixel }}=\Sigma\left[\mathrm{C}_{\mathrm{e}} \cdot \rho(\lambda)_{\mathrm{e}}\right]+\varepsilon \\
& \quad=\left[\mathrm{C}_{\mathrm{pv}} \cdot \rho(\lambda)_{\mathrm{pv}}+\mathrm{C}_{\mathrm{npv}} \cdot \rho(\lambda)_{\text {npv }}+\mathrm{C}_{\text {substrate }} \cdot \rho(\lambda)_{\text {substratel }}\right]+\varepsilon,
\end{aligned}
$$

where $\rho(\lambda)_{\mathrm{e}}$ is the reflectance of each land-cover endmember (e) at wavelength $\lambda$ and $\varepsilon$ is an error term. Solving for the subpixel cover fractions $\left(\mathrm{C}_{\mathrm{e}}\right)$ requires that the observations $\left(\rho(\lambda)_{\text {pixel }}\right.$-in this case, Landsat ETM+ reflectance) contain sufficient spectral information to solve a set of linear equations, each of the form in equation (1) but at different wavelengths $(\lambda)$. The end-member reflectance bundles used in the AutoMCU code were compiled from field and satellite data as described in detail by Asner et al. [2005]. Although no spectra were collected in the field in Rondônia, the AutoMCU method, which allows for uncertainty in end-member spectral properties as well as Landsat spectral calibration [Asner et al., 2005], has proven sufficiently generic to allow its use across a wide range of vegetation and soil conditions throughout Brazil and Peru [Asner et al., 2003, 2004; Oliveira et al., 2007]. The output from the model included subpixel PV, NPV and S along with standard deviations caused by uncertainty in both the reflectance imagery (following atmospheric correction) and the spectral end-members.

\subsection{Evaluation of Management Effects at Nova Vida}

[12] Local records of pasture management treatments, including liming, herbiciding, and disking during the period 1998-2001 were obtained from the managers of Fazenda Nova Vida. Because we had no prior knowledge regarding the time required for treatment effects to be detected or to dissipate, we decided to compare the treatment record to the mean PV, NPV, and S values derived from analysis of three dry season images, obtained on 9 August 1999, 24 August 2000, and 11 August 2001. This multidate "mean" image of the PV, NPV and S components was created using the spatial modeling function in ERDAS 9.0 software. The three geo-registered images (e.g., PV-1999, PV-2000, PV2001) were averaged pixel by pixel. This was done for each of the three bands (PV, NPV, and S) and the output was written to a new file containing the new three-banded image with average of the three dates for each band.

\section{Results and Discussion}

\subsection{Spatial Variation Within Ranches}

[13] False color images of Fazenda Vitória and Fazena Nova Vida are shown in Figure 1. Shadows and water appear as black, and remnant mature forests appear as red, owing to high values of PV. The pastures appear with a range of colors, indicating various combinations of $\mathrm{S}$ (blue), NPV (green) and PV (red). Yellow indicates a mixture of predominantly PV and NPV, whereas magenta indicates a mixture of predominantly PV and S. Pasture management units included in this study are indicated by yellow polygons.

\subsection{Variation in PV, NPV, and $S$ as Scalars of Degradation}

[14] The variation in PV, NPV, and S across all pasture management units in both ranches of this study and the ranches near the Santarém area [Asner et al., 2004] are plotted in a ternary diagram in Figure 2. Most of the pasture management units fall along a line for which PV decreases as NPV and S increase. Using these scalars, the most degraded sites would be identified with the highest NPV and $\mathrm{S}$ values of fractional cover. A continuum of degrees of degradation is apparent rather than a sharp cutoff point for categorizing a pasture as clearly degraded or not. The degraded old pastures and the still-productive young pastures described by Asner et al. [2004] near Santarém span the range of these variables and are good examples of highly degraded and productive pasture end-members of this continuum. Two of these highly degraded old pastures are outliers from the linear pattern in Figure 2, with values $>40 \%$ for exposed soil. In general, pastures within Fazenda Vitória, Pará, have higher values of PV and lower values of NPV and $\mathrm{S}$ than do the pastures of Fazenda Nova Vida in Rondônia, indicating that the latter is somewhat more degraded as defined by these scalars.

\subsection{Seasonal Variation Within Fazenda Nova Vida}

[15] As expected, values of PV were higher during the wet season compared to the dry season at Fazenda Nova Vida (Figure 3). This seasonal variation highlights the

Figure 1. False color images of (a) Fazenda Vitória, Pará and (b) Fazenda Nova Vida, Rondônia, based on spectral mixture analysis of Landsat images from the dry season. Black indicates no data for those pixels, typically due to the presence of shadows or water. Red indicates high values for photosynthetic vegetation (PV); green indicates high values for nonphotosynthetic vegetation (NPV); blue indicates high values for exposed soil (S); yellow is a mixture of predominantly PV and NPV; blue-green is a mixture of predominantly NPV and S; and magenta is a mixture of predominantly PV and soil. 


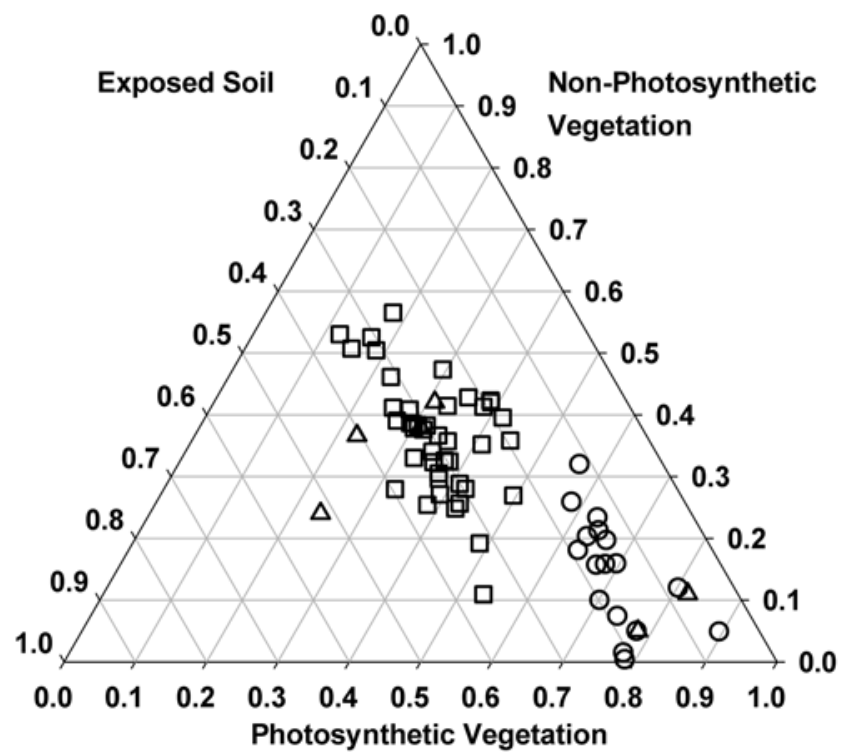

Figure 2. Ternary diagram of PV, NPV, and S values for each pasture management unit at Fazenda Vitória (circles), Fazenda Nova Vida (squares), and various ranches near Santarém (triangles [Asner et al., 2004]) from dry season imagery.

importance of accounting for seasonality when making comparisons among two or more Landsat scenes, a finding reported by Numata et al. [2007a, 2007b] as well. Nevertheless, the fraction of $\mathrm{S}$ did not vary substantially between dates (Figure 3), indicating that this indicator was less affected by seasonality. Similarly, we do not know how recently cattle were rotated through pasture management units and when other management activities occurred relative to the date of each scene, which potentially introduces additional temporal variation.

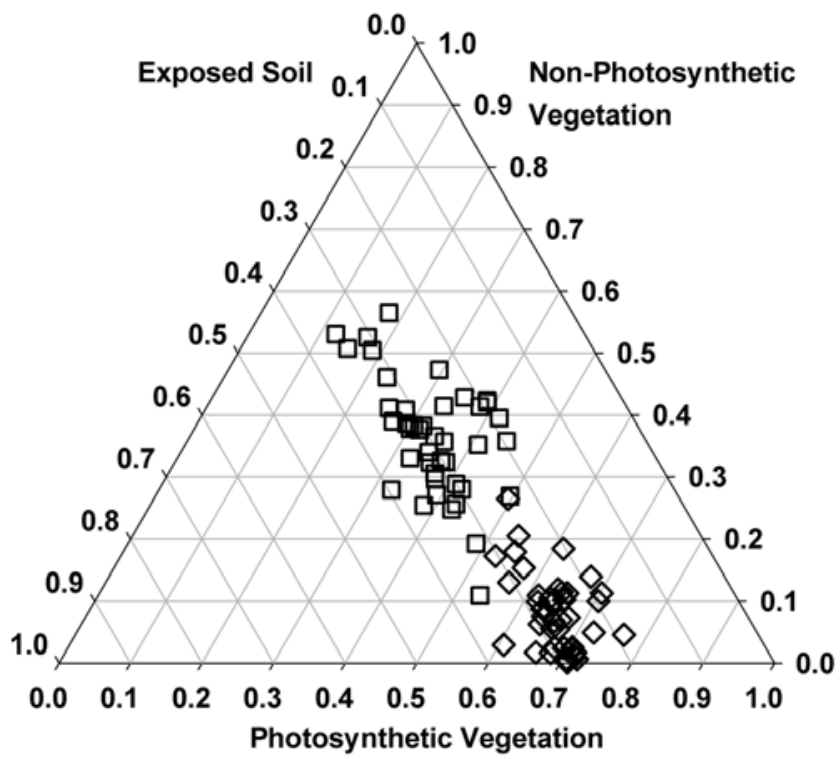

Figure 3. Ternary diagram of PV, NPV, and S values for dry season (squares) and wet season (diamonds) at Fazenda Nova Vida, Rondônia.

\subsection{Spatial Variation Within Fazenda Nova Vida: Management Intensity}

[16] The managers of the intensively managed Nova Vida ranch maintained a GIS database of their pastures and the treatments that each has received during the period 1998 2001, including disking, herbiciding, and liming. We summed these treatments for this period for each pasture management unit. The number of treatments is weakly, but significantly positively correlated with the degradation scalar of NPV and negatively correlated with the productivity indicator of PV (Figure 4). These results may have occurred for two reasons. First, treatments likely led to a reduction in cover and biomass of weedy broadleaf vegetation that would have contributed to higher PV. Second, assuming that the pastures that received the greatest number of treatments also received the greatest average grazing pressure, then it follows that the most used pastures would have the greatest amount of senescent foliage relative to green foliage. Additional coordinated field and satellite measurements could help to verify these possibilities.

\subsection{Variation Among Ranches and Management Intensity}

[17] When the two ranches of this study are combined with the ranches near Santarém, Pará [Asner et al., 2004], the three areas represent a gradient in management intensity (Table 1). The Santarém ranches had the lowest stocking rates $(0.25 \mathrm{head} / \mathrm{ha})$ and also the fewest inputs (no fertilizer, liming, or other treatments). The Santarém ranches included old pastures that had been in production for 15 years and very young pastures (converted from forest 2 years earlier). The managed pastures at Fazenda Vitória, near Paragominas, Pará, had intermediate cattle stocking (1.0 head/ha), had been graded once, and received $\mathrm{P}$ amendments approximately once every five years. Other pastures at Fazenda

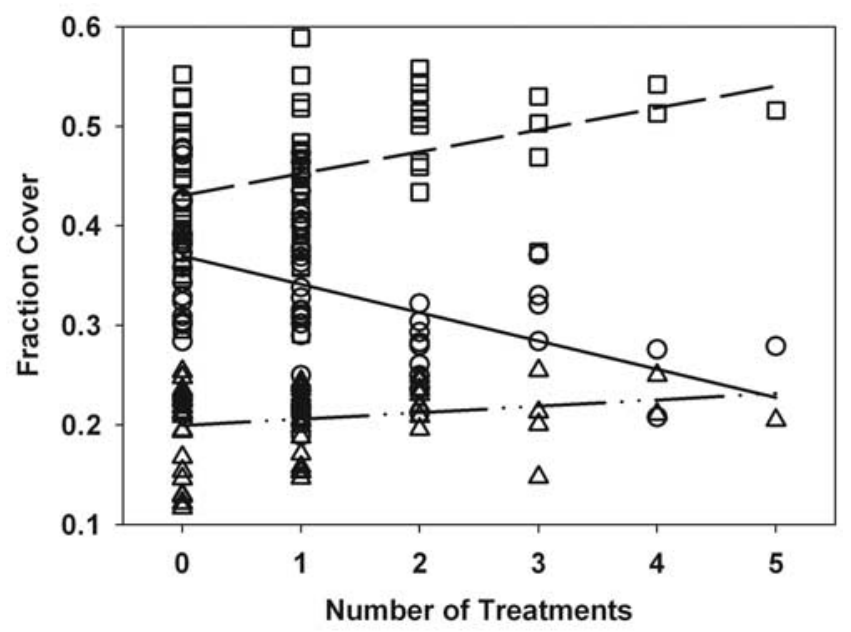

Figure 4. Correlations among the number of treatments (1998-2001) on record for each pasture management unit at Fazenda Nova Vida, Rondônia, and values of PV (circles), NPV (squares), and $\mathrm{S}$ (triangles). The regression lines are: $\mathrm{NPV}=0.022 \mathrm{x}+0.431 ; \mathrm{R}^{2}=0.14 ; \mathrm{p}=0.0025$, dashed line; $\mathrm{PV}=-0.028 \mathrm{x}+0.370, \mathrm{R}^{2}=0.20, \mathrm{p}=0.0003$, solid line; $\mathrm{S}=$ $0.006 x+0.200, R^{2}=0.04, p=0.096$, dash-dotted line, where $\mathrm{x}$ is the number of recorded treatments. 
Table 1. Comparison of Management Histories and Soils Among Study Regions

\begin{tabular}{lclc}
\hline & Nova Vida, Ariquemes, Rondônia & \multicolumn{1}{c}{ Vitória, Paragominas, Pará } & Various near Santarém, Pará \\
\hline Stocking (head/ha) & $1.5-1.8$ & 1.0 & 0.25 \\
Treatments & disking, herbiciding, liming & disking and P fertilization; abandonment & no inputs \\
Dominant soils & Ultisols & Oxisols & Oxisols \\
Pasture age (years) & $13-91$ & $14-32$ & $2-15$ \\
\hline
\end{tabular}

Vitória had been abandoned. Fazenda Nova Vida, in Rondônia, had the highest stocking (1.5-1.8 head/ha) and received the most intensive management, including grading, liming, and herbiciding treatments. The Ultisols at Nova Vida are also more fertile than are the Oxisols of the study areas in Pará [Davidson et al., 2004].

[18] Although these objectively determined scalars of degradation indicate that the Nova Vida ranch shows signs of pasture degradation, cattle production nevertheless remains high $(1.5-1.8 \mathrm{head} / \mathrm{ha})$ in these pastures owing to intensive management and relatively high inputs. Management actions that decrease weed cover and that are accompanied by increased grazing may decrease PV and increase NPV, thus appearing to push pastures toward degradation, while, in fact, these pastures remain highly productive and actively used. Hence, the Nova Vida example shows that management can trump the tendency toward degradation and can maintain sufficient productivity for the cattle operation to be economically viable over several decades [Feigl et al., 2006] despite some emerging signs of exposed soil and senescent vegetation reported here. Exposed soil does not exceed $40 \%$ of the area in any of the Nova Vida pastures, and is probably less when cattle are first moved into a management unit. Some of the pixels with the highest values of S appear to be areas at corners of fields or at feeding and watering stations where cattle tend to congregate.

[19] While this remote sensing technique, and others like it [e.g., Numata et al., 2003, 2007a], successfully reveals variation in objectively defined degradation indicators among and within ranches, these degradation indicators do not necessarily imply reduced current cattle production potential that cannot be overcome with sufficient inputs and intensity of management. With sufficient inputs and management intensity, degradation can be kept at bay and productivity maintained even in old pastures, at least in some regions, as demonstrated here for the Fazenda Nova Vida in Rondônia. Absent such inputs, however, even pastures that are grazed with only $0.25 \mathrm{head} / \mathrm{ha}$ can become degraded in less than 2 decades, as demonstrated by the pastures near Santarém (Figure 2 [Asner et al., 2004]).

[20] Numata et al. [2007a, 2007b] suggested that pasture degradation in response to stocking rates is largely controlled by soil type, with more fertile Alfisols sustaining the most cattle per area without apparent losses due to degradation. Although no sites on Alfisols were included in the current study, the Ultisols of the Rondônia site are more fertile than are the Oxisols of the sites in Pará, and we find a similar trend as Numata et al. [2007b], that ranchers tend to invest the most in terms of management intensity where the soils are most fertile. The combination of naturally more fertile soils and greater management inputs appear to have kept severe pasture degradation from developing in these sites with high stocking rates. More work needs to be done to identify the appropriate combinations of site properties, climate, and management inputs needed for sustainable cattle production. The remote sensing tools presented here may aid such analyses over large spatial scales.

[21] Finally, where values of PV are high, as in many of the pastures of Fazenda Vitória, this indicator may show either green pasture grasses or the green foliage of shrubs and small trees in recently abandoned pastures. The two management units with the highest PV values at Fazenda Vitória were abandoned pastures with significant coverage by young secondary forest vegetation. Some ranchers might consider such pastures as degraded, and remote sensing scientists often call such pastures "dirty pastures." Such pastures are not necessarily degraded from the biological perspective of net primary productivity, but rather have been invaded and, in some cases, overgrown by native plants that are considered nuisances by the ranchers. These sites would presumably become secondary forests with significant rates of $\mathrm{C}$ sequestration and recuperation of forest plant diversity if management interventions do not return them to productive pastures. Hence, the scalars of degradation provided by this analysis are indicative of degradation from an ecological sense, i.e., the capacity for net primary productivity, rather than a direct measure of pasture productivity from a management and cattle production perspective.

\section{Conclusions}

[22] The objectively determined scalars of degradation described here, using estimates of pixel coverage by photosynthetic vegetation, nonphotosynthetic vegetation, and exposed soil reveal patterns that are related to the interplay of grazing intensity and management intensity. Where both grazing and management intensities are high, cattle production can be maintained despite indications of incipient degradation by the NPV and S scalars. Where both inputs and grazing intensity are low, young pastures initially appear with high PV scores that decline with pasture age as NPV and S increase. High values of PV can indicate either highly productive pastures or vigorous regrowth of native vegetation where pasture abandonment has not been preceded by severe degradation.

[23] Neither grazing intensity nor management intensity, alone, can explain the observed patterns, but grazing pressure relative to management inputs explains variation within and among ranches. Similar conclusions regarding legacies of pasture management intensity and use have been reached regarding aboveground [Zarin et al., 2005] and belowground [Dias-Filho et al., 2001; Neill and Davidson, 2000] carbon stocks. The remote sensing based scalars presented here provide insight into pasture degradation processes, but, rather than providing a simple objective scalar that can be universally applied to assessments of pasture degradation, their interpretation requires knowledge 
of the site management characteristics. The method holds promise for identifying areas where grazing intensity has exceeded management inputs for sufficiently long periods to induce significant increases in coverage of senescent foliage and exposed soil.

[24] Acknowledgments. This research was supported by grant NNG06GE88A of NASA's Terrestrial Ecology Program as part of the Large-scale Biosphere-Atmosphere Experiment in Amazonia (LBA) project.

\section{References}

Asner, G. P., and K. B. Heidebrecht (2002), Spectral unmixing of vegetation, soil and dry carbon cover in arid regions: Comparing multispectral and hyperspectral observations, Int. J. Remote Sens., 23, 3939-3958, doi:10.1080/01431160110115960.

Asner, G. P., A. R. Townsend, and M. C. M. Bustamante (1999), Spectrometry of pasture condition and biogeochemistry in the central Amazon, Geophys. Res. Lett., 26, 2769-2772, doi:10.1029/1999GL900546.

Asner, G. P., M. M. C. Bustamante, and A. R. Townsend (2003), Scale dependence of biophysical structure in deforested areas bordering the Tapajo's National Forest, central Amazon, Remote Sens. Environ., 87, 507-520, doi:10.1016/j.rse.2003.03.001.

Asner, G. P., A. R. Townsend, M. M. C. Bustamante, G. B. Nardoto, and L. P. Olander (2004), Pasture degradation in the central Amazon: Linking changes in carbon and nutrient cycling with remote sensing, Global Change Biol., 10, 844-862, doi:10.1111/j.1529-8817.2003.00766.x.

Asner, G. P., D. E. Knapp, E. N. Broadbent, P. J. C. Oliveira, M. Keller, and J. N. Silva (2005), Selective logging in the Brazilian Amazon, Science, 310, 480-482, doi:10.1126/science.1118051.

Bastos, T. X., and T. D. Diniz (1982), Avaliação de clima do Estado de Rondônia para desenvolvimento agrícola, Bol. Pesquisa 44, EmbrapaCPATU, Belém, Brazil.

Clapperton, C. (1993), Quaternary Geology of South America, Elsevier Sci., New York.

Davidson, E. A., C. Neill, A. V. Krusch, V. V. R. Ballester, D. Markewitz, and R. D. O. Figueiredo (2004), Loss of nutrients from terrestrial ecosystems to streams and the atmosphere following land use change in Amazonia, in Ecosystems and Land Use Change, Geophys. Monogr. Ser, vol. 153, edited by R. Defries et al., pp. 147-158, AGU, Washington, D. C.

Davidson, E. A., et al. (2007), Recuperation of nitrogen cycling in Amazonian forests following agricultural abandonment, Nature, 447(7147), 995-998, doi:10.1038/nature05900.

Dias-Filho, M., E. A. Davidson, and C. J. R. D. Carvalho (2001), Linking biogeochemical cycles to cattle pasture management and sustainability in the Amazon Basin, in The Biogeochemistry of the Amazon Basin, edited by M. E. McClain et al., pp. 84-105, Oxford Univ. Press, New York.

Feigl, B., C. Cerri, M. Piccolo, N. Norohna, K. Agusti, J. Melillo, V. Eschenbrenner, and L. Melo (2006), Biological survey of a lowproductivity pasture in Rondônia state, Brazil, Outlook Agric., 35, $199-208$

Jipp, P., D. C. Nepstad, K. Cassel, and C. J. R. D. Carvalho (1998), Deep soil moisture storage and transpiration in forests and pastures of seasonally-dry Amazonia, Clim. Change, 39(2/3), 395-412, doi:10.1023/ A: 1005308930871.
Markewitz, D., E. Davidson, P. Moutinho, and D. Nepstad (2004), Nutrient loss and redistribution after forest clearing on a highly weathered soil in Amazonia, Ecol. Appl., 14(4), 177-199, doi:10.1890/01-6016.

Neill, C., and E. A. Davidson (2000), Soil carbon accumulation or loss following deforestation for pasture, in Global Climate Change and Tropical Ecosystems, edited by R. Lal et al., pp. 197-211, CRC Press, Boca Raton, Fla.

Neill, C., M. C. Piccolo, C. C. Cerri, P. A. Steudler, J. M. Melillo, and M. Brito (1997), Net nitrogen mineralization and net nitrification rates in soils following deforestation for pasture across the southwestern Brazilian Amazon Basin landscape, Oecologia, 110, 243-252, doi:10.1007/ s004420050157.

Nepstad, D. C., C. Uhl, and E. A. S. Serrão (1991), Recuperation of a degraded Amazonian landscape: Forest recovery and agricultural restoration, Ambio, 20, 248-255.

Numata, I., J. V. Soares, D. A. Roberts, F. C. Leonidas, O. A. Chadwick, and G. Batista (2003), Relationships among soil fertility dynamics and remotely sensed measures across pasture chronosequences in Rondonia, Brazil, Remote Sens. Environ., 87, 446-455, doi:10.1016/j.rse. 2002.07.001.

Numata, I., D. A. Roberts, O. A. Chadwick, J. P. Schimel, F. R. Sampaio, F. C. Leonidas, and J. V. Soares (2007a), Characterization of pasture biophysical properties and the impact of grazing intensity using remotely sensed data, Remote Sens. Environ., 109, 314-327, doi:10.1016 j.rse.2007.01.013.

Numata, I., D. A. Roberts, Y. Sawada, O. A. Chadwick, J. P. Schimel, and J. V. Soares (2007b), Regional characterization of pasture changes through time and space in Rondonia, Earth Interact., 11, doi:10.1175/ EI232.1.

Oliveira, P. J., G. P. Asner, D. E. Knapp, A. Almeyda, R. GalvanGildemeister, S. Keene, R. F. Raybin, and R. C. Smith (2007), Land-use allocation protects the Peruvian Amazon, Science, 317, 1233-1236, doi:10.1126/science. 1146324

Projeto Radambrasil (1978), Levantamento de recursos naturais, Dep. Nac. de Prod. Miner., Min. das Minas e Energ., Rio de Janeiro.

Serrão, E. A. S., and J. M. Toledo (1990), The search for sustainability in Amazonian pastures, in Alternatives to Deforestation: Steps Toward Sustainable use of the Amazon Rain Forest, edited by A. B. Anderson, pp. 195-214, Columbia Univ. Press, New York.

Sombroek, W. G. (1966), Amazon Soils: A Reconnaissance of the Soils of the Brazilian Amazon Region, 300 pp. Pudoc, Wageningen, Netherlands.

Vermote, E. F., D. Tanre, J. L. Deuze, M. Herman, and J. J. Morcrette (1997), Second simulation of the satellite signal in the solar spectrum, 6S: An overview, IEEE Trans. Geosci. Remote Sens., 35, 675-686, doi: $10.1109 / 36.581987$

Zarin, D. J., et al. (2005), Legacy of fire slows carbon accumulation in Amazonian forest regrowth, Front. Ecol. Environ., 3, 365-369.

G. P. Asner, Department of Global Ecology, Carnegie Institution, 260 Panama Street, Stanford, CA 94305, USA. (gasner@globalecology. stanford.edu)

E. A. Davidson and T. A. Stone, Woods Hole Research Center, 149 Woods Hole Road, Falmouth, MA 02540-1644, USA. (edavidson@ whrc.org)

R. O. Figueiredo, Embrapa Amazônia Oriental, Av. Dr. Enéas Pinheiro, Belem, Pará 66095-100, Brazil. (ricardo@cpatu.embrapa.br) C. Neill, Ecosystems Center, Marine Biological Laboratory, 7 MBL Street, Woods Hole, MA 02543, USA. (cneill@mbl.edu) 